\title{
THE Updated COMMENTARY ON THE FIRST GENEVA CONVENTION - A NEW TOOL FOR GENERATING RESPECT FOR INTERNATIONAL HUMANITARIAN LAW ${ }^{*}$
}

Lindsey Cameron, Jean-Marie Henckaerts, Bruno Demeyere, Eve La Haye \& Heike Niebergall-Lakner ${ }^{* *}$

TABLE OF CONTENTS

I. A CONTEMPORARY INTERPRETATION OF HUMANITARIAN

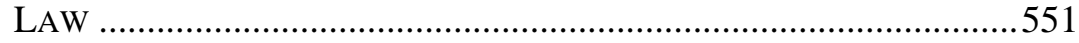

II. THE UPDATING OF THE COMMENTARY IN A NUTSHELL ..................553

III. EXAMPLES OF EVOLUTIONS IN THE INTERPRETATIONS SiNCE

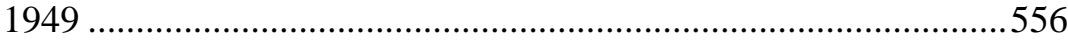

A. Common Articles ......................................................................557

1. The Duty to Respect and Ensure Respect Found in Common Article 1 ..............................................................557

2. Classification of Armed Conflict in Common Article 2 .....558

3. The Regulation of Non-international Armed Conflicts in Common Article 3 .........................................................559

4. Offer of Services in Common Articles 3 and 9...................561

B. Developments in Other Areas..................................................562

1. Protection of the Wounded and Sick..................................562

2. The Duty to Disseminate ......................................................563

3. Criminal Repression of Breaches .....................................563

C. Some Cross-cutting Issues.......................................................564

1. A Gender Perspective to Interpreting the First

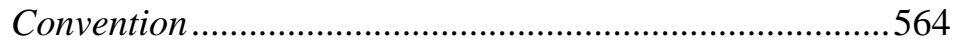

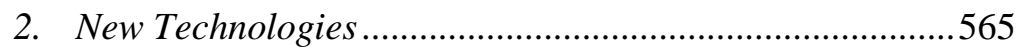

D. Specific Issues Related to State Practice ..................................566

1. Areas Where There Has Been Little Practice Since

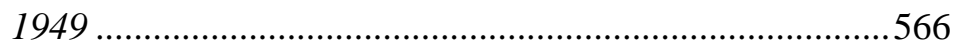

2. Procedures in the Convention That Have Not Been Applied as Such................................................................567

\footnotetext{
* This Article was originally published in 97 Int'l Rev. Red Cross, no. 900, 2015, at 120926. It is reprinted with permission.

** Legal Advisors in the Commentaries Update Unit in the Legal Division of the ICRC.
} 
3. State Practice Diverging from the Literal Meaning of the Text................................................................................568

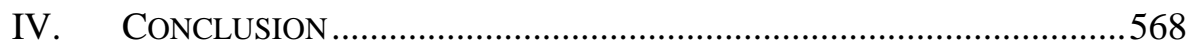


KEYWORDS: International humanitarian law, First Geneva Convention, updated Commentary, International Committee of the Red Cross, State practice, protection of wounded and sick, non-international armed conflict, duty to respect and ensure respect, classification of armed conflict, offer of services, gender, dissemination, criminal repression.

\section{A CONTEMPORARY INTERPRETATION OF HUMANITARIAN LAW}

In 2011, the ICRC, along with a number of renowned external experts embarked on a major project: updating the Commentaries on the Geneva Conventions of 1949 and their Additional Protocols of 1977. ${ }^{1}$ Since the drafting of the original Commentaries in the 1950s and 1980s, the Geneva Conventions and their Additional Protocols have been put to the test on numerous occasions, and there have been significant developments in how they are applied and interpreted in practice. With the project of updating all six Commentaries, the ICRC seeks to ensure that these developments are captured in the Commentaries and that up-to-date and comprehensive interpretations of the law are provided. The project is carried out as part of the ICRC's role "to work for the understanding and dissemination of knowledge of international humanitarian law” (IHL) and for its faithful application. ${ }^{2}$

With the completion of the updated Commentary on the First Geneva Convention on the Protection of the Wounded and Sick of Armed Forces in the Field, the first major milestone has been reached. The Commentary is available free of charge on the ICRC website. ${ }^{3}$

The First Convention elaborates the fundamental obligation of IHL that was originally championed by the founders of the ICRC, i.e., that the wounded and sick members of the armed forces are to be respected and protected in all circumstances, be treated humanely and cared for, whether friend or foe. As such, the First Convention more than any other IHL treaty represents the embodiment of Henry Dunant's idea that the soldier who is wounded or sick, and who is therefore hors de combat, is from that moment

\footnotetext{
${ }^{1}$ See Jean-Marie Henckaerts, Bringing the Commentaries on the Geneva Conventions and their Additional Protocols into the twenty-first century, 94 INT'L REv. RED CROss, no. 888, 2012, at 1551-55.

${ }^{2}$ See Statutes of the International Red Cross and Red Crescent Movement, 1986, Arts. 5(2)(g), (4), https://www.icrc.org/eng/resources/documents/misc/statutes-movement-220506. htm.

${ }^{3}$ See https://ihl-databases.icrc.org/ihl/full/GCI-commentary. A hard-copy version will be published by Cambridge University Press in the second half of 2016 and the Commentary, which is currently available in English only, will be translated into Arabic, Chinese, French, Russian and Spanish.
} 
inviolable. ${ }^{4}$ As an essential condition for the wounded and sick to be collected and cared for, protection is also afforded to military medical personnel, units, material and transports. Furthermore, the First Convention contains the provisions relating to the use and protection of the emblem, both reaffirming the protective function of the emblem and clarifying the restrictions on its use.

However, the importance of this milestone further derives from the fact that the updated Commentary on the First Convention also provides updates on the articles common to all four Geneva Conventions. Among these are articles which are central to the application and protection provided by the four Conventions, such as common Article 1 dealing with the obligation to respect and to ensure respect for the Conventions in all circumstances and common Article 2 defining their scope of application. Within the group of common articles, common Article 3 stands out in particular, as it is the only provision in the universally ratified 1949 Geneva Conventions that was specifically designed to govern non-international armed conflicts. ${ }^{5}$ Neither the drafters of the 1949 Geneva Conventions, nor the drafters of the initial Commentary in 1952 could foresee the prevalence that non-international armed conflicts would take in the decades following the adoption of the Convention. The new Commentary takes this prevalence into account and analyses the legal regime contained in common Article 3 in unprecedented detail.

This Article provides a brief overview of the process of updating the Commentary on the First Convention and summarizes the main evolutions in interpretations of the treaty norms since 1949 that have been found in State practice and international jurisprudence and literature. The examples listed in this summary are not exhaustive but they serve to highlight the continued relevance of international humanitarian law in contemporary armed conflicts. Throughout the Article references to the updated Commentary guide the reader to more detailed discussions of the topics listed.

\footnotetext{
${ }^{4}$ For a description of the circumstances that led to the founding of the ICRC and the International Red Cross and Red Crescent Movement, starting with the battle of Solferino and culminating in the adoption of the first Geneva Convention in 1864, see Francois Bugnion, Birth of an idea: the founding of the International Committee of the Red Cross and of the International Red Cross and Red Crescent Movement, 94 InT'L REV. RED CROss, no. 888, 2012, at 1299-1338, https://www.icrc.org/eng/resources/documents/article/review-2012/irrc888-bugnion.htm.

${ }^{5}$ In comparison, Additional Protocol II is not universally ratified and its scope of application is more limited, without, however, modifying common Article 3's existing conditions of application. For the current status of the Conventions and Protocols, http:// www.icrc.org/eng/resources/documents/misc/party_main_treaties.htm.
} 


\section{THE UPDATING OF THE COMMENTARY IN A NUTSHELL}

The 2016 Commentary on the First Convention, as well as the updated Commentaries on the Second, Third and Fourth Convention and on the Additional Protocols that are currently still worked on, aim to contribute to the clarification of IHL by providing contemporary, thoroughly researched interpretations of IHL.

It preserves the format of the 1952 Commentary (also known as the Pictet Commentary), that is to say an article-by-article commentary on each of the provisions of the Convention. It is based on research that includes an analysis of State practice in the application and interpretation of the treaties, e.g., in military manuals, national legislation or official statements; interpretations and clarifications provided in case law and scholarly writings. Additionally, the contributors to the Commentary were able to draw on research in the ICRC Archives and to reflect the application and interpretation of the Convention since its adoption in light of the practice witnessed by the ICRC in past armed conflicts.

In the updated Commentary, practitioners and scholars will find detailed information relevant for a comprehensive understanding of each provision in the First Convention. The updated Commentary provides a picture of the current understandings of the law. This not only includes interpretations supported by the ICRC, but also indications where there are diverging views or were there are issues that are not settled and require further discussion. As such, it is not the final word but a solid basis for further discussion about the implementation, clarification and development of IHL. Importantly, it serves as a new guidance tool for States, international organizations, courts and humanitarian actors in their efforts aimed at reasserting the importance of IHL and at generating respect for the law.

The drafting process of the updated Commentary has benefited from considerable external involvement and has thus gone far beyond the drafting process of the initial Pictet Commentaries. Authors drafting one of the updated commentaries to a specific article had the opportunity to read and comment on the updated commentaries on all other articles of the Convention. This review provided a layer of scrutiny and helped to ensure that the interpretations are coherent throughout the Commentary. Furthermore, the whole commentary was reviewed by an Editorial Committee which includes senior ICRC and non-ICRC lawyers. ${ }^{6}$

\footnotetext{
6 The external members of the Editorial Committee are Liesbeth Lijnzaad and Marco Sassòli, the ICRC members are Philip Spoerri and Knut Dörmann. Information on authors/members of the Reading Committee as well as on the group of Peer Reviewers can be
} 
In addition, more than sixty practitioners and academics from all corners of the world have been asked to peer review the draft Commentary and have provided valuable comments and input into the final product. This elaborate process helped to ensure that all main views were taken into account. ${ }^{7}$ As a result, the updated Commentary reflects the ICRC's interpretation of the law, whenever there is one, and presents the main schools of thought where divergences of views exist on the interpretation of any particular provision. Given the Commentary's nature as an interpretative and practical guidance tool, however, it should be noted that there has been no formal consultation process with States as part of the drafting process.

In preparing the updated commentary, the authors followed the rules of the Vienna Convention on the Law of Treaties on treaty interpretation, in particular, Articles 31-32 VCLT. They looked at the ordinary meaning of the terms of the provisions and its context, the preparatory work and subsequent practice, in the form of State practice (or sometimes the absence thereof) and case-law, as well as other relevant rules of international law. ${ }^{8}$

Other relevant rules of international law include customary IHL, the three Additional Protocols, as well as other treaties of international law, such as those relating to international criminal law and human rights law. ${ }^{9}$ When the Geneva Conventions were adopted, many areas of international law were still in their infancy, like human rights law, international criminal law and refugee law, but they have grown significantly in the meantime. These areas of law all seek to provide protection to persons in need of it. IHL is not a self-contained body of law but interacts with these other areas of international law in a way that it is often complementary. Therefore, the interpretations offered in the new Commentary take the developments in these areas into account whenever required for a comprehensive interpretation of a Convention rule. In addition, there are developments in

found in the Acknowledgements to the Commentary, see https://ihl-databases.icrc.org/ihl/full/ GCI-commentaryAckAbb.

7 See, e.g., Commentary on Article 12 of the First Convention, section E.1.

${ }^{8}$ For more details on the methodology, please refer to the General Introduction of the Commentary, https://ihl-databases.icrc.org/ihl/full/GCI-commentaryIntroduction.

${ }^{9}$ It should be noted that treaties, other than the Conventions themselves, that are referred to in the Commentaries are used on the understanding that they only apply if all the conditions in terms of their geographic, temporal and personal scope of application are fulfilled. In addition, they only apply to States that have ratified or acceded to them, unless they are reflective of customary international law. 
other areas of international law, such as the law on State responsibility or the law of treaties which are also reflected in the new Commentary. ${ }^{10}$

With respect to international human rights law, the new Commentary does not purport to discuss every aspect of the complex relationship between rules of the Geneva Convention and human rights law. Rather, based on the premise of the complementary nature of both bodies of law, the new Commentary refers to human rights law wherever relevant, for example in order to interpret shared concepts (e.g., cruel, inhuman and degrading treatment). ${ }^{11}$

Human rights law may also be referenced where the application of the Conventions may be affected by international human rights obligations. The use of the death penalty is an example. While common Article 3 as well as Articles 100 and 101 of the Third Convention and Article 68 of the Fourth Convention anticipate the possibility of the use of the death penalty, the updated commentaries on these Articles would be incomplete without a reference to international treaties aiming to abolish the death penalty. ${ }^{12}$ These references are not so much a matter of interpreting the obligations in the Conventions through the lens of human rights law, but of mentioning parallel obligations in order to provide a complete overview of the relevant international legal rules.

With respect to international criminal law, the growing body of case law from the various international criminal courts and tribunals, as well as national courts, provides material illustrating the way in which identical or similar concepts and IHL obligations have been applied and interpreted for the purpose of assessing individual criminal responsibility. To the extent that this case law is relevant for the interpretation of the Conventions, it has been examined.

Another example is the 1979 International Convention against the Taking of Hostages, which has become a starting point for the interpretation of the notion of the taking of hostages. This is also borne out by subsequent practice, e.g., in the form of the war crime of hostage-taking in the ICC

\footnotetext{
${ }^{10}$ For examples on State responsibility, see e.g., the commentary on common Article 1, paras 144, 160 and 190 and on common Article 2, paras. 267-270. For an example on the law of treaties, and in particular the law on succession to treaties, see Article 60, section C.4.

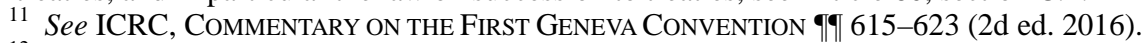

12 European Convention for the Protection of Human Rights and Fundamental Freedoms, 213 UNTS 222, 4 November 1950 (entered into force 3 September 1953), Protocol 6; International Covenant on Civil and Political Rights, 999 UNTS 171, 16 December 1966 (entered into force 23 March 1976), Second Optional Protocol; and American Convention on Human Rights, 1144 UNTS 123, 22 November 1969 (entered into force 18 July 1978), Protocol to Abolish the Death Penalty.. See the commentary on Common Article 3, para. 677.
} 
Statute of 1998 and the definition in the ICC Elements of Crimes of 2002 and case-law. ${ }^{13}$

That being said, it is important to underscore that a humanitarian treaty obligation may be broader than the criminalized parts of it in a rule contained in an instrument of international criminal law. IHL treaty obligations exist independently of the rule of international criminal law on which the case law is founded. The content of the obligation may therefore not be identical in both bodies of law and differences are pointed out wherever they exist. For example, under IHL a biological experiment is outlawed even if it does not cause death or seriously endanger the health of the victim. However, for such an experiment to reach the threshold of a grave breach under Article 50, it must seriously endanger the health or integrity of the protected person. In this respect, the scope of the criminal responsibility for conducting biological experiments is more restricted than the scope of the prohibition to carry out such experiments in IHL. ${ }^{14}$

\section{EXAMPLES OF EVOLUTIONS IN THE INTERPRETATIONS SINCE 1949}

The Pictet Commentary was based primarily on the negotiating history of the respective treaties, as observed first hand by the authors, and on prior practice, especially that of the Second World War. They contain important institutional and historical knowledge and, in this respect, retain their value.

Over six decades later, the updated Commentary on the First Convention is able to offer a more detailed approach that takes into account the issues and challenges witnessed in contemporary armed conflicts, the developments in technology and in international and national law. The analysis carried out in preparing the updated Commentary reaffirms many of the 1952 interpretations, but it also departs from them in certain cases.

The analysis has shown that circumstances for the application of some of the provisions of the First Convention that had received much attention during the Diplomatic Conference have rarely arisen. Consequently, these provisions have not had the relevance in armed conflicts since the Second World War that was attached to them during the Diplomatic Conference. In other cases, subsequent practice and the developments in international law have meant that the commentaries on certain provisions were considerably expanded-in substance and in length. The following paragraphs will provide examples of these findings.

\footnotetext{
13 For details, see the commentary on common Article 3, section G.3.

14 ICRC, supra note 11, para. 2994. Another example would be the prohibition of violence to life, see id. para. 886.
} 


\section{A. Common Articles}

\section{The Duty to Respect and Ensure Respect Found in Common Article 1}

One evolution in interpretation contained in the new Commentary relates to common Article 1 which requires States to "respect and ensure respect" for the Conventions. While the 1952 Pictet Commentary stated that common Article 1 was not applicable in non-international armed conflicts, the updated Commentary, based on developments over the last six decades, concludes that it is. ${ }^{15}$ This interpretation corresponds with the fundamental nature of common Article 3, which has been qualified by the ICJ as a "minimum yardstick" in the event of any armed conflict. ${ }^{16}$

The interpretation of common Article 1 today is influenced by the practice of States, international organizations and courts who have recognized the obligation to respect and ensure respect in both its internal and external aspects. The internal aspect covers States' obligation to respect and ensure respect for the Conventions by their own armed forces and other persons or groups whose conduct is attributable to them, as well as by the whole population over which they exercise authority. ${ }^{17}$ The external aspect relates to ensuring respect by others, in particular other parties to a conflict regardless of whether the State itself is party to that conflict. This external aspect has become increasingly important. ${ }^{18}$

Based on practice the new Commentary gives further details on the negative and positive obligations that comprise the external aspect of the obligation. Under the negative obligation States must abstain from encouraging, aiding or assisting in violations of the Conventions. The positive obligations require States to take proactive steps to bring violations of the Conventions to an end and to bring an erring Party to a conflict back to an attitude of respect for the Conventions, in particular by using their influence on that Party. The duty to ensure respect is to be carried out with due diligence. This means that its content depends on the specific circumstances, including the gravity of the breach, the means reasonably available to the State, and the degree of influence it exercises over those

\footnotetext{
15 See ICRC, supra note 11, paras. 125-126, as compared to Jean Pictet (ed.), Commentary on the Geneva Conventions of 12 August 1949, Vol 1: Geneva Convention for the Amelioration of the Wounded and Sick in Armed Forces in the Field, ICRC, Geneva, 1952, at 26.

${ }^{16}$ ICJ, Military and Paramilitary Activities in and against Nicaragua case, Merits, Judgment, 1986, para. 218.

17 See the commentary on common Article 1, sections E.1 and E.2.

18 See the commentary on common Article 1, section E.3.
} 
responsible for the breach. The new commentary also provides a list of examples of steps States can take to ensure respect for IHL.

\section{Classification of Armed Conflict in Common Article 2}

The updated commentary takes into account the various types of international armed conflicts that have arisen in the period since the Pictet commentaries were published. For instance, the updated Commentary affirms that an armed conflict can arise when one State unilaterally uses armed force against another State even if the latter does not or cannot respond by military means. The simple fact that a State resorts to the use of armed force against another suffices to qualify the situation as an armed conflict within the meaning of the Geneva Conventions. ${ }^{19}$

The evaluation of military involvement by a foreign State in a noninternational armed conflict in the updated Commentary is an example of how interpretations have evolved over the past decades adjusting to the complexities of contemporary multi-party conflicts. While the ICRC had suggested to the 1971 Conference of Government Experts that the military involvement by a foreign State in a non-international armed conflict internationalizes the conflict as a whole, making IHL governing international armed conflict applicable in relations between all the opposing Parties, ${ }^{20}$ a differentiated approach has become widely accepted and is today also followed by the ICRC. This approach distinguishes between whether an outside State fights in support of a State or non-State Party to the conflict. The armed conflict will remain non-international in the first case, because it continues to oppose a non-State armed group and State armed forces. While the original armed conflict between the non-State armed group and the State armed forces also remains non-international in character in the second case, a parallel international armed conflict between the intervening foreign State and the State party to the original armed conflict also arises, because in that instance two States are opposed. Lastly, where several foreign States intervene on either side of the original non-international armed conflict, the international or non-international character of each bilateral conflict

19 ICRC, supra note 11, paras. 222-223.

20 The proposal read: "When, in case of non-international armed conflict, one or the other Party, or both, benefits from the assistance of operational armed forces afforded by a third State, the Parties to the conflict shall apply the whole of the IHL applicable in international armed conflicts"; Conference of Government Experts on the Reaffirmation and Development of International Humanitarian Law Applicable in Armed Conflicts, Report on the work of the Conference, ICRC, Geneva, 1971, p. 50. Among the reasons noted by the experts to reject the proposal was that it would encourage non-international armed groups to seek support from foreign States; see id. pp. 51-52. 
relationship will depend on whether the opposing Parties only consist of States or involve non-State armed groups. ${ }^{21}$

The updated Commentary also addresses issues such as the question of the classification of the conflict in a situation where a State controls an organized non-State armed group that is fighting another State. The question of the degree of control the State must exercise over the armed group in order for the whole conflict to be classified as international has arisen in different instances in international courts and tribunals. ${ }^{22}$ While acknowledging that views diverge on the necessary level of control for the purposes of attribution under the law of State responsibility and for the purpose of classifying conflicts as international or non-international, the Commentary sets out the view of the ICRC that "the overall control test is appropriate because the notion of overall control better reflects the real relationship between the armed group and the third State, including for the purpose of attribution."23

\section{The Regulation of Non-international Armed Conflicts in Common} Article 3

It is almost a platitude to observe that the vast majority of armed conflicts in the last sixty years have been non-international in nature. Owing to this fact, common Article 3 has become a central provision of IHL. The quality of common Article 3 as a "Convention in miniature" for conflicts of a noninternational character was already noted during the 1949 Diplomatic Conference. $^{24}$ Since then, the fundamental character of its provisions has

\footnotetext{
${ }^{21}$ For details see ICRC, supra note 11, paras. 402-405.

${ }^{22}$ See for example International Criminal Court for the Former Yugoslavia (ICTY), The Prosecutor v. Dusko Tadic, Case No. IT-94-1-A, Judgment (Appeals Chamber), 15 July 1999, paras. 102-145; International Court of Justice (ICJ), Case Concerning Application of the Convention on the Prevention and Punishment of the Crime of Genocide (Bosnia and Herzegovina v. Serbia and Montenegro), Judgement, ICJ Reports 2007, paras. 404-405. For a discussion of these cases and the tests they applied, see ICRC, supra note 11, paras. 265-273.

${ }^{23}$ For a discussion of the overall control test, see ICRC, supra note 11, paras. 265-273, in particular para. 271.

${ }^{24}$ See Diplomatic Conference for the Establishment of International Conventions for the Protection of War Victims, Final Record of the Diplomatic Conference of Geneva of 1949, Vol. II-B, p. 326. At the time, this expression was used to point out the brevity and selfcontained character of the draft ultimately adopted as common Article 3, in distinction to other approaches considered at the Diplomatic Conference that would have made certain provisions of the Geneva Conventions as such applicable in non-international armed conflicts.
} 
been recognized as a "minimum yardstick," binding in all armed conflicts, and as a reflection of "elementary considerations of humanity.",25

The updated Commentary addresses the various legal issues surrounding the circumstances in which this miniature Convention operates. These issues include the geographical and temporal scope of application of common Article $3,{ }^{26}$ its binding force on non-State armed groups and on multinational forces ${ }^{27}$ the persons protected, ${ }^{28}$ fundamental obligations of the parties to a non-international conflict, ${ }^{29}$ humanitarian activities, ${ }^{30}$ special agreements, ${ }^{31}$ and the legal status of the parties to the conflict. ${ }^{32}$

To take one example, the updated commentary elaborates on what the obligation to collect and care for the wounded and sick-which is expressed rather in summary form in common Article 3-entails. The interpretation draws on the general obligation in common Article 3 to treat the wounded and sick humanely to emphasize that the wounded and sick must be respected and protected. It also relies on the detail set out in Additional Protocol II and the rules of customary IHL to complete the assessment of the protections that are considered implicit in the basic obligation to care for the wounded and sick, including the protection of medical personnel, facilities, and transports and the use of the emblem, to name a few. ${ }^{33}$

Furthermore, it is now recognized that serious violations of Common Article 3, such as murder, torture, and hostage-taking, also constitute war crimes in non-international armed conflicts as recognized as a matter of the ICC Statute and customary IHL. ${ }^{34}$ The commentary on common Article 3 discusses these prohibitions in light of the case law of international criminal courts and tribunals, as well as in national courts. ${ }^{35}$ In addition, discussions on a number of other legal debates regarding the protection available in noninternational armed conflicts have been added to the new Commentary, such as the prohibition of sexual violence, ${ }^{36}$ the applicability of the principle of

\footnotetext{
${ }^{25}$ See ICJ, Military and Paramilitary Activities in and against Nicaragua, Judgment, ICJ Reports 1986, paras. 218-219.

${ }^{26}$ ICRC, supra note 11, paras. 452-502.

27 Id. paras. 503-517.

${ }^{28}$ Id. paras. 518-549.

${ }^{29}$ Id. paras. $550-580$.

${ }^{30}$ Id. paras. $779-840$.

${ }^{31}$ Id. paras. 841-860.

32 Id. paras. 861-869.

33 Id. paras. 768-778.

${ }^{34}$ Id. paras. $581-695$.

${ }^{35}$ Id. paras. 870-903.

${ }^{36}$ Id. paras. 696-707.
} 
non-refoulement during non-international armed conflict $^{37}$ and detention outside a criminal process. ${ }^{38}$

Another example relates to the prohibition of sexual violence. This prohibition is only explicitly mentioned in the Geneva Conventions in relation to international armed conflict (see Article 27 of the Fourth Geneva Convention). However it is also implicitly mentioned for non-international armed conflicts in the Geneva Conventions in the obligation of humane treatment. The Commentary references the case law and the statutes of international criminal tribunals and concludes that sexual violence is prohibited in all armed conflicts, as it can amount to violence to life and person, torture, mutilation, or cruel treatment, all of which are absolutely prohibited. $^{39}$

\section{Offer of Services in Common Articles 3 and 9}

Another evolution can be found in the interpretation of common Article 9 and common Article 3(2) regarding the offer of services, by the ICRC or other impartial humanitarian organizations, in international and noninternational armed conflicts. While the 1952 Commentary stated that the decision whether to consent to humanitarian activities on their territory was entirely up to the belligerent Power and no reason needed to be given for refusing an offer of services, ${ }^{40}$ the new Commentary concludes that, nowadays, such an offer of services may not be refused on arbitrary grounds. Since 1949, international law in general, and IHL in particular, has evolved and it has now become accepted that the Party to the conflict whose consent is sought must assess an offer of services in good faith and in line with its international legal obligations in relation to humanitarian needs. ${ }^{41}$ Thus, where a Party to an armed conflict is unwilling or unable to address those humanitarian needs, it must accept an offer of services from an impartial humanitarian organization. If humanitarian needs cannot be met otherwise, the refusal of an offer of services from an impartial humanitarian organization would be arbitrary, and therefore in violation of international law. $^{42}$

37 Id. paras. 708-716.

38 Id. paras. 717-728.

39 Id. paras. 696-707.

$40 \mathrm{~J}$. Pictet (ed.), supra note 15, at 110.

${ }^{41}$ ICRC, International Humanitarian Law and the challenges of contemporary armed conflicts, report to the 31st International Conference of the Red Cross and Red Crescent, ICRC, Geneva, 2011, p. 25.

${ }^{42}$ ICRC, supra note 11, paras. 833-834, 1173-1174. 


\section{B. Developments in Other Areas}

\section{Protection of the Wounded and Sick}

The principal objective of the First Geneva Convention is to ensure the respect and protection of wounded and sick members of the armed forces in times of armed conflict. Warfare has evolved enormously since this idea was first set down in international treaty law in 1864 and has continued to evolve since the adoption of the Geneva Conventions in 1949. The updated commentary on Article 12, while taking into account the contemporary context in which the wounded and sick must be respected and protected, affirms that this obligation remains a cornerstone of IHL. With the benefit of the precise definitions set out in Additional Protocol I, the updated commentary on Article 12 confirms that the decisive criteria for determining whether a member of the armed forces is wounded or sick are that the person is in need of medical care, no matter the gravity of the condition, and refrains from any act of hostility. ${ }^{43}$

Furthermore, the updated Commentary captures the key aspects of the obligation to respect and protect the wounded and sick, from taking their presence into account in a proportionality assessment when planning and conducting attacks, ${ }^{44}$ to affirming the prohibition against so-called "dead check" or "double tap," 45 to the general obligation to have medical services in the first place. ${ }^{46}$ In addition, the updated Commentary points to the need to consider the potential presence of civilians and medical personnel rushing to the scene of an attack to provide care when contemplating (and before carrying out) a second strike on a military objective. ${ }^{47}$

Finally, in the decades since 1949, there has been debate on a topic of tremendous operational relevance to military authorities: whether military medical personnel, units and transports may be armed and, if so, which limits apply. The First Geneva Convention itself only deals with that topic in one place: Article 22(1) which stipulates that the fact that "the personnel of the (military medical) unit or establishment are armed, and that they use the arms in their own defense, or in that of the wounded and sick in their charge" may not be considered as a condition to deprive that unit or establishment of its protection. Thus the Convention remains silent altogether as to whether

43 Id. paras. 1341-1351.

44 Id. paras. 1355-1357.

${ }^{45}$ Id. para. 1404. Both terms refer to a practice of intentionally shooting the wounded to make sure they are dead.

${ }^{46}$ Id. para. 1750.

47 Id. paras. 1749-1750. 
weapons may be mounted on these units. The same situation arises when looking at the provisions dealing with military medical transports, including medical aircraft. Finally, whereas the principle that military medical personnel may be armed is recognized by the quoted provision, the text provides no guidance as to the applicable limits, if any, in terms of type of weapons they may be provided with, nor in terms of the circumstances in which they may be used. The updated Commentary discusses in which way the law on this question, left unaddressed by the First Convention, has developed, and also analyses the implications of the arming of military medical personnel, units and transports has in terms of the entitlement to display the distinctive emblem of the Geneva Conventions. ${ }^{48}$

\section{The Duty to Disseminate}

While the Pictet Commentary primarily reflected the conviction of the drafters at the time that the spreading of knowledge would, in and of itself, generate respect, the new Commentary takes into account empirical research that indicates that knowledge alone does not suffice to induce a favorable attitude towards a norm and that military doctrine, education, training and equipment, as well as sanctions, are key factors in shaping the behavior of weapon bearers during military operations.

The updated Commentary states that in order to be effective, IHL must not be taught as an abstract and separate set of legal norms, but must be integrated into all military activity, training and instruction. Such integration should aim to inspire and influence the military culture and its underlying values, in order to ensure that legal considerations and principles of IHL are incorporated, as much as possible, into military doctrine and decision-making. ${ }^{49}$

\section{Criminal Repression of Breaches}

Article 49 of the First Convention deals with the suppression of abuses and penal sanctions and a similar provision has been incorporated in all four 1949 Geneva Conventions. The new commentary on Article 49 was considerably expanded in order to reflect the important developments in this

\footnotetext{
${ }^{48}$ Id.; see paras. 1862-1869, 2005-2006, 2393-2402, 2449.

49 ICRC, supra note 11, paras. 2773-2776. For more on this, see Andrew J. Carswell, Converting Treaties into Tactics on Military Operations, 96 InT'L REV. Of THE RED CROss, nos. 895/896, 2014, pp. 919-42, https://www.icrc.org/en/international-review/article/convert ing-treaties-tactics-military-operations; Elizabeth Stubbins Bates, Toward Effective Military Training in International Humanitarian Law, 96 INT'L REV. OF THE RED CROss, Nos. 895/896, 2014, pp. 795-816, https://www.icrc.org/en/international-review/article/towards-effective-mi litary-training-international-humanitarian-law.
} 
field over the past decades. While the historical background section of Article 49 is shorter than in the 1952 predecessor version, the updated Commentary covers entirely new issues, such as an overview of how States have implemented the grave breaches regime in their domestic legislation, as well as an analysis of the concept of universal jurisdiction and its interpretation by States. ${ }^{50}$ It also contains critical assessments on whether the grave breaches regime contained in Article 49 has functioned and an analysis of whether States have prosecuted and/or extradited suspected war criminals on the basis of the Geneva Conventions, ${ }^{51}$ discussions of the concept of immunity of Heads of States, ${ }^{52}$ and the possible extension of the grave breaches regime to non-international armed conflicts. ${ }^{53}$

The developments in international criminal law and in particular the case law of the International Criminal Tribunal for the former Yugoslavia (ICTY), International Criminal Tribunal for Rwanda (ICTR), Special Court for Sierra Leone (SCSL) and more recently the ICC have allowed more refined definitions of a number of prohibitions of IHL both in international and in non-international armed conflicts, such as the prohibition of murder, torture, mutilation or, as mentioned above, the prohibition of biological experiments in common Article 3 and Article 12 of the First Convention.

\section{Some Cross-cutting Issues}

\section{A Gender Perspective to Interpreting the First Convention}

The updated Commentary describes, where relevant, how the application in practice of a provision may affect women, men, girls and boys differently. The reference in the original Commentary to women as "weaker than oneself and whose honour and modesty call for respect" would no longer be considered appropriate. $^{54}$ Of course, the original Commentaries were a product of the social and historical context of the time. Today, however, there is a deeper understanding that women, men, girls and boys have specific needs and capacities linked to the different ways armed conflict may affect them. The new Commentary reflects this understanding in relevant articles and takes into account the social and international legal developments in relation to equality of the sexes.

${ }^{50}$ ICRC, supra note 11, paras. 2863-2867.

${ }^{51}$ Id. paras. 2857-2858.

52 Id. paras. 2872-2877.

53 Id. paras. 2903-2905.

54 See J. Pictet (ed.), supra note 15, at 140. 
In addition to the updated commentary on Article 12(4) of the First Convention that deals specifically with the treatment of women, ${ }^{55}$ examples of the inclusion of a gender perspective in the revised Commentary on the First Geneva Convention can be found in the discussions of concepts such as humane treatment, non-adverse distinction and the obligation to care for the wounded and sick in common Article 3 and in Article $12,{ }^{56}$ and in the commentaries on Articles 6, 11, 23 and 31 of the First Convention. ${ }^{57}$

\section{New Technologies}

A contemporary interpretation of IHL requires that new technologies and their impact on warfare are taken into account when discussing the application of specific treaty rules.

For example, it is nowadays recognized that the marking of medical facilities might also involve the communication of GPS coordinates to other Parties in addition to, or in lieu of, marking them with the distinctive emblem. ${ }^{58}$ GPS coordinates may also help to identify persons and indicate the exact location of graves. ${ }^{59}$

Another example is the use of email to transmit information as the quickest method of communication. ${ }^{60}$ Email might also be used to communicate a warning where warnings are required under IHL. ${ }^{61}$ While the use of GPS coordinates and email to enhance the protection foreseen in the Geneva Convention is uncontroversial, the application of IHL with regard to other technologies is more challenging and often still an issue of debate. The updated Commentary discusses these challenges and captures the current debate, for example regarding the question of treating cyber operations as armed force amounting to armed conflict, ${ }^{62}$ or the issue of drone strikes and the obligation to collect and care for wounded and sick in Article 15 of the First Convention. ${ }^{63}$

A last example in this regard is the possibility of DNA sampling that creates new opportunities with regard to the identification and collection of information about the wounded and sick or the dead. The updated

55 ICRC, supra note 11, paras. 1427-1429, 1435.

${ }^{56}$ Id. paras. 553, 578, 766, 1362, 1373, 1395.

57 Id. paras. 966, 1293, 1931, 2273.

${ }^{5}$ Id. paras. 775, 2649.

59 Id. paras. 1577, 1667, 1713.

60 On forwarding of information under Article 16 by e-mail, see id. paras. 1593 and 1598; on communication of ratifications or accessions by e-mail see para. 3259.

61 See id. para. 1850

${ }^{62}$ Id. paras. 253-256.

63 Id. para. 1491. 
Commentary discusses these opportunities and the safeguards required for the use of DNA sampling and analysis. ${ }^{64}$

\section{Specific Issues Related to State Practice}

\section{Areas Where There Has Been Little Practice Since 1949}

For a number of provisions, the review of State practice and court cases has revealed that these provisions have played little to no role in armed conflicts since 1949. The new Commentary indicates this and evaluates for these cases whether a rule has fallen into desuetude. Examples are Articles 28, 30 and 31 of the First Convention which regulate the conditions under which military medical and religious personnel and staff of voluntary aid societies may be retained when they have fallen into enemy hands. While belligerent Parties had retained large numbers of enemy medical personnel over extended periods of time during the Second World War, ${ }^{65}$ such practice has proven to be rare in international armed conflicts since 1949. While the Commentary concludes that the provisions governing retention remain applicable and relevant to the issue, research has shown that the number of international armed conflicts in which they have been called upon to play a role has decreased over time. ${ }^{66}$ Another example is the placing of staff of national aid societies, such as of a Red Cross or Red Crescent Society, at the disposal of army medical services. While this remains a valid option, it has not occurred in recent decades and thus the articles related to this personnel, their material and their identification have not played a very significant role since $1949 .{ }^{67}$

The appointment of Protecting Powers as regulated in Article 8 of the First Convention represents another example. While the Diplomatic Conference of 1949 made the Protecting Powers the lynchpin of the system for monitoring compliance with the Geneva Conventions in international armed conflict, practice since 1949 has not developed in this direction and the appointment of Protecting Powers in case of an international armed conflict has been the exception rather than the rule. Since the 1949 Conventions were adopted, Protecting Powers are only known to have been appointed in five conflicts. ${ }^{68}$ Seemingly, practice since 1949 has evolved to

${ }^{64}$ Id. paras. 1584, 1661, 1673.

65 See J. Pictet (ed.), supra note 15, at 237.

${ }^{66}$ For a recent example of return of medical personnel, see id. para. 2610.

67 See the commentaries on Articles 26, 27, 32, 34 and 43.

68 Protecting powers are known to have been appointed in the Suez Conflict (1956) between Egypt on one side and France and the United Kingdom on the other, the conflict between 
the point of considering the appointment of Protecting Powers as optional in nature. This does not preclude, however, that Protecting Powers may still be appointed in future international armed conflicts on the basis of Article $8{ }^{69}$

The absence of practice in the application of a provision does not, in and of itself, lead to the falling into desuetude of such a provision. Desuetude means that a treaty rule is no longer applicable or has been modified, a conclusion that should not be reached lightly. It is subject to stringent conditions and requires the agreement, at least tacit, of the parties or the emerging of an inconsistent rule of customary international law. ${ }^{70}$ Although certain provisions do not seem to have been applied extensively in the past six decades, no evidence has been found that would suggest that they no longer apply.

\section{Procedures in the Convention That Have Not Been Applied as Such}

For certain procedures foreseen in the Geneva Convention, research has revealed that State practice has diverted from the exact formulas foreseen in the Geneva Convention, but has nevertheless followed the underlying principles and rationale of these mechanisms foreseen by the drafters.

State practice indicates that the use of good offices that were foreseen as part of the conciliation procedures in Article 11 of the First Convention in practice were used flexibly and have not been limited to activities purely facilitating contacts between opposing Parties. Taking into account this evolution, as well as the humanitarian purpose of Article 11, the updated Commentary clarifies that reference to "good offices" in paragraph 1 should not be understood restrictively and allow for the use of any diplomatic initiatives that may serve the interest of protected persons. ${ }^{71}$

Similarly, the enquiry procedure as foreseen in Article 52 of the First Convention so far has never been used. This does not mean that the general idea behind the provision to investigate alleged violations of IHL has been rejected. On the contrary, such investigations take place regularly in the form of formal investigations on the initiative and under the aegis of the international community, through investigation procedures within the UN system or fact-finding as part of the work undertaken by international

France and Tunisia over Bizerte (1961), the Goa crisis (1961) between India and Portugal, the conflict between India and Pakistan (1971), and the Falkland/Malvinas Islands' conflict between Argentina and the United Kingdom (1982), see ICRC, supra note 11, para. 1115.

${ }^{69}$ See the commentary on Article 8, section $\mathrm{H}$.

70 See ICRC, supra note 11, paras. 51-52 with further references.

71 For a definition of the term 'good offices' in international law and how its understanding has evolved, see id. paras. 1282-1286. 
criminal tribunals. Despite the fact that the enquiry procedure under the 1949 Geneva Conventions has not been used so far, the updated Commentary does not conclude that the provision has fallen into desuetude, and some experts still support it as a potentially attractive option for the purposes of enhancing compliance for IHL. ${ }^{72}$

\section{State Practice Diverging from the Literal Meaning of the Text}

With regard to certain provisions, research has revealed that the practice of States has not followed the literal meaning of the text, but nevertheless adhered to the general ideas and principles underlying the provisions. Article 38 of the First Convention, for example, provides for the use of the red crescent (or red lion and sun) only "in the case of countries which already use as emblem, in place of the red cross, the red crescent or the red lion and sun on a white ground." Technically, this means that none of the dozens of new States created or established since 1949 would be in a position to choose to adopt an emblem other than the red cross upon becoming a party to the Geneva Conventions. However, a thorough examination of State practice revealed that no State has ever insisted on this rule, demonstratingin essence-a belief that there should be no hierarchy among the distinctive emblems. $^{73}$ The updated Commentary thus reflects the equality of the distinctive emblems, including the red crystal, which is also confirmed in the 2005 Third Additional Protocol. ${ }^{74}$

The evolution of the way Article 8 on Protecting Powers is interpreted can also be seen as a departure from the strict reading of the text. The obligation that the Convention "shall be applied with the cooperation and under the scrutiny of the Protecting Powers" is today no longer seen as an obligation but rather an option. ${ }^{75}$

\section{CONCLUSION}

The work required to update the Commentary on the First Convention has shown that the Convention is as relevant today as it was at the time of its adoption. While warfare is changing and new weapon systems are being developed, armed conflicts continue to be characterized by scores of people

${ }^{72}$ Id. paras. 3059-3064.

${ }^{73}$ Id. paras. 2547-2551.

${ }^{74}$ See Article 2 of the Third Additional Protocol Additional relating to the adoption of an additional distinctive emblem of 8 December 2005.

${ }^{75}$ For details, see the commentary on Article 8, section $\mathrm{H}$. 
in urgent need of protection. The Geneva Conventions provide such protection and are of burning relevance today.

The First Convention has proven to be crucial for ensuring the care and protection of the wounded and sick of the armed forces, and for the protection of military medical personnel, units and transports. It has had a profound influence on the development of national military policies and procedures and on resource allocation, training and implementation. On the basis of the Convention's rules, the ICRC calls upon States to abide by certain standards of treatment of the wounded and sick in times of armed conflict; and these rules, among others, enable the ICRC to carry out its humanitarian mission in the field and to offer humanitarian activities during armed conflict.

Nevertheless, armed conflicts continue to cause suffering that States had hoped to eradicate when agreeing on the four revised and partly new Conventions in 1949. Disrespect of the law remains the biggest challenge for all those committed to alleviating human suffering during war. The Commentaries on the Geneva Conventions and their Additional Protocols represent an important guidance tool in the efforts of the ICRC, States, international organizations, courts and humanitarian actors to generate respect for the law.

The updated Commentary on the First Geneva Convention is the first in a series of updated Commentaries to be published by the ICRC over the coming years. Currently, research is ongoing with regard the protection of the wounded, sick and shipwrecked members of the armed forces at sea (Second Convention), the protection of prisoners of war (Third Convention) and the protection of civilians in time of war (Fourth Convention). Updated Commentaries will be published consecutively on these Conventions, as well as on their Additional Protocols I and II over the coming years. Next, the updated Commentary on the Second Geneva Convention is scheduled to be published in 2017. 